\title{
EFEKTIVITAS HEDGING KONTRAK FUTURES KOMODITI EMAS DENGAN OLEIN
}

\author{
Fitri Ismiyanti (fitri.ismiyanti@feb.unair.ac.id) \\ Hendra Ima Sasmita \\ Departemen Manajemen, Fakultas Ekonomi dan Bisnis, Universitas Airlangga
}

\begin{abstract}
This research is for comparing hedging effectiveness in gold and olein commodity. Using Ordinary Least Square (OLS) model to determine the hedge ratio, it's found that olein hedge ratio is bigger than gold hedge ratio. The value of olein hedge ratio is bigger than gold hedge ratio indicate that to eliminate loss in olein spot market is needed a lot of futures contract as compared to eliminate loss in gold spot market. However, independent t-test to return hedged variance both commodity show there is no different variance. This mean the return hedged variance of gold commodity has the same value with olein return hedged variance. So, handling the systematic risk of olein hedger have the same as of gold hedger handling. With the result that, if doing hedging strategy and there is no same instrument to be hedged in futures market, so hedger may considering to use cross hedging strategy, but previously determined first the optimum hedge ratio, because the optimum hedge ratio can reduce the variance return caused by market risk (systematic risk).
\end{abstract}

Keywords: Hedge Ratio, Return Hedged Variance, and Hedging Effectiveness.

\section{PENDAHULUAN}

Latar Belakang

Berkembangnya pasar keuangan yang semakin pesat turut meningkatkan risiko yang akan dihadapi investor, sehingga diperlukan diversifikasi untuk mengurangi risiko ini. Diversifikasi portofolio secara internasional merupakan pilihan untuk mengurangi atau meminimalkan tingkat risiko yang akan dihadapi. Hal ini dikarenakan perbedaan kondisi perekonomian suatu negara yang berbeda satu sama lain dapat menyebarkan tingkat risiko, sehingga memperkecil tingkat volalitas return portofolio.

Bagi investor dengan tipe penghindar risiko, pemilihan diversifikasi portofolio internasional tidaklah cukup. Diversifikasi internasional hanyalah untuk mengurangi risiko non-systematic, namun risiko pasar (systematic risk) masih tetap ada. Oleh karena itu, untuk mengurangi risiko pasar diperlukan suatu instrumen lindung nilai yang dapat menurunkan tingkat varians return. Hal ini dapat dilakukan dengan menambahkan kontrak derivative sebagai instrumen lindung nilai (hedging).

Hull (2008:45) menyebutkan bahwa lindung nilai yang sempurna adalah dengan mengeleminasi semua risiko, namun perfect hedging merupakan hal yang sangat jarang sekali adanya. Dengan menggunakan kontrak derivative diharapkan dapat mendekatkan pada kondisi lindung nilai yang sesempurna mungkin. Sehingga, nantinya diharapkan imbal hasil yang diperoleh dapat sesuai dengan imbal hasil yang telah diperkirakan (expected return).

Berbagai instrumen derivative dapat digunakan sebagai alat lindung nilai, diantaranya berupa kontrak futures, forward, option, dan swaps. Di Indonesia sendiri kontrak derivative yang sudah diterbitkan dan mulai banyak digunakan adalah kontrak futures. Baik kontrak futures pada instrumen keuangan seperti saham, maupun pada instrumen komoditi. 
Kontrak futures merupakan sebuah kesepakatan untuk membeli atau menjual aset pada harga dan waktu tertentu dimasa yang akan datang (Hull, 2008:21). Dengan menggunakan kontrak futures diharapkan dapat melakukan pencegahan risiko terhadap pergerakan harga pada pasar spot yang tidak diinginkan. Jika pasar futures dan pasar tunai bergerak bersamaan, setiap kerugian yang diderita oleh hedgers pada satu posisi dapat diimbangi dengan laba pada posisi lainnya. Oleh karena itu laba dan kerugian diharapkan memiliki nilai yang sama.

Hull (2008:25) menyebutkan bahwa selama masa pencapaian periode delivery, harga dari sebuah kontrak futures akan mendekati/hampir mendekati (convergence) dari harga spot atas underlying asetnya. Ketika harga futures melebihi dari harga spot, para trader akan mencoba memanfaatkan peluang arbitrase ini hingga pada akhirnya harga dari futures akan jatuh. Begitu juga sebaliknya ketika harga dari futures berada dibawah harga spot, para investor akan mengambil peluang ini untuk menaikkan aset mereka dengan membeli kontrak futures hingga menunggu jatuh tempo (delivery), sehingga harga dari futures akan cenderung naik mendekati harga spotnya. Kedua hal ini menunjukkan bahwa harga futures akan mendekati atau sangat mendekati dari harga spotnya selama periode delivery.

Pasar futures merupakan alternatif pasar yang dapat dimanfaatkan untuk mengubah tingkat risiko suatu aktiva pada saat diperoleh suatu informasi baru. Kecepatan dalam mengubah posisi saat informasi baru diperoleh dibutuhkan untuk mencapai tujuan investasi dengan lebih efisien. Kecepatan ini tercermin pada pasar futures dengan pertimbangan likuiditas, biaya transaksi, kecepatan pelaksanaan, dan leverage, sehingga pengubahan portofolio dengan menggunakan futures akan lebih mudah dan murah dibandingkan dengan pasar tunai (Fabozzi, 2000:413). Lindung nilai dapat diterapkan baik untuk instrumen keuangan maupun instrumen komoditi. Pada lindung nilai instrumen keuangan bisa mengunakan kontrak futures indeks, seperti Indeks LQ45 futures, sedangkan pada instrumen komoditi, di Indonesia telah ada kontrak futures emas, kontrak futures olein, kontrak gulir emas, dan kontrak gulir indeks emas yang diselenggarakan oleh Bursa Berjangka Jakarta (BBJ). Kontrak gulir indeks biasanya digunakan untuk menghedge posisi valuta karena pada kontrak gulir ini merupakan perbandingan harga penutupan pada Bursa Berjangka Jakarta dengan Loco London, sehingga pergerakannya serupa dengan pergerakan antara Rupiah dengan US Dollar.

Bursa komoditi mempertemukan pembeli dan penjual untuk memperdagangkan kontrak berjangka atas komoditi. Pada mulanya, bursa komoditi digunakan oleh petani dan produsen untuk melindungi kedua belah pihak dari fluktuasi harga. Hingga saat ini, selain dimanfaatkan oleh petani dan produsen, bursa komoditi juga dimanfaatkan oleh spekulator yang melakukan pembelian dan penjualan kontrak berjangka untuk mendapatkan keuntungan serta menyediakan likuiditas terhadap sistem perdagangan berjangka.

Komoditi yang umumnya ditransaksikan adalah kopi, kakao, gula, kedelai, jagung, emas, tembaga, kapas, lada, gandum, CPO (crude palm oil, minyak sawit mentah), katun, susu, logam (emas, perak, nikel), dan juga kontrak berjangka yang menggunakan komoditi sebagai aset acuannya. Kontrak berjangka ini mencakup harga spot, kontrak serah, kontrak berjangka, dan opsi berjangka.

Pada Bursa Berjangka Jakarta terdapat dua komoditi utama yang diperdagangkan sebagai kontrak berjangka, emas dan olein. Emas merupakan barang tambang olahan dengan kemilau yang indah, sehingga banyak digunakan sebagai bahan perhiasan. Selain sebagai perhiasan, emas juga digunakan sebagai alat penyimpan kekayaan dikarenakan nilainya yang tidak mudah berfluktuasi jika dibandingkan dengan kondisi nilai tukar mata uang. Sedangkan olein adalah produk turunan dari minyak sawit mentah (CPO). Minyak sawit banyak digunakan sebagai bahan makanan dan industri melalui proses penyulingan, penjernihan dan penghilangan bau atau RBDPO (Refined, Bleached and Deodorized Palm Oil). 
Berdasarkan latar belakang di atas, penelitian ini menggunakan komoditi emas dan olein sebagai acuan. Emas merupakan instrumen yang kebanyakan masyarakat Indonesia percaya bahwa nilainya akan terus mengalami kenaikan, sehingga sangat ideal sebagai alat lindung nilai terhadap pergerakan inflasi. Sedangkan Olein merupakan komoditi yang bersifat global sebagai bahan baku utama industri, sehingga banyak diperdagangkan dikalangan dunia. Dari alasan tersebut, peneliti hendak membandingkan efektivitas lindung nilai yang dilakukan oleh hedger emas dengan hedger olein dengan membandingkan perbedaan varians return hedgednya.

Penelitian ini berbeda dengan penelitian yang dilakukan sebelumnya. Bhargava (2007), meneliti perbandingan rasio yang optimal terhadap kontrak futures pasar komoditas kapas dengan kedelai. Penelitian ini menggunakan data dari tahun 1995 hingga 2000, dengan menggunakan 10 model yang digolongkan dalam tiga kategori yakni, metode tradisional regresi, metode regresi yang di modifikasi, dan model error-correction. Hasil dari penelitian ini mengidentifikasikan bahwa metode regresi yang dimodifikasi dan model error-correction mampu menunjukkan efektivitas hedging menggunakan kontrak futures dari komoditas kapas dan kedelai.

Hasil penelitian Ripple dan Moosa (2004), futures hedging lebih efektif ketika menggunakan nilai yang mendekati akhir kontrak. Pada penelitian ini data yang digunakan adalah data harian dan bulanan dari crude oil futures dengan harga spotnya pada New York Mercantile Exchange (NYMEX) untuk mengukur rasio hedge selama periode pengamatan dari 2 Januari 1998 hingga 29 April 2005. Kesimpulan dari penelitian ini menyatakan bahwa rasio hedge akan lebih rendah pada nilai yang mendekati akhir kontrak.

Penelitian yang dilakukan oleh Agustina (2006) yang membandingkan rasio hedge indeks LQ45 Futures dengan menggunakan 3 model yakni OLS, VAR, dan VECM menunjukkan adanya perbedaan rasio hedge dengan menggunakan ketiga model, namun tidak menunjukkan adanya perbedaan yang signifikan terhadap efektivitas hedging. Sedangkan penelitian ini bertujuan untuk membandingkan varians return hedged komoditi emas dengan varians return hedged komoditi olein. Data yang digunakan dalam penelitian ini merupakan data sekunder yang diolah dari berbagai sumber. Periode pengamatan penelitian ini dilakukan selama 5 tahun dari bulan Januari 2005 hingga Januari 2010, dimana bulan Mei 2005 tidak dimasukkan kedalam variabel penelitian dikarenakan ketidaktersediaan data.

\section{Rumusan Permasalahan}

Berdasarkan latar belakang permasalahan di atas, maka permasalahan yang dapat dirumuskan adalah apakah terdapat perbedaan efektivitas dalam penanganan risiko sistimatis yang dihadapi oleh hedger komoditi emas dengan hedger komoditi olein?

Tujuan Penelitian

Tujuan penelitian ini adalah untuk mengetahui efektivitas penanganan risiko sistimatis yang dihadapi oleh hedger komoditi emas dengan hedger komoditi olein dengan menguji perbedaan varians return hedged pada kontrak futures komoditi emas dengan varians return hedged pada kontrak futures komoditi olein.

\section{TELAAH PUSTAKA DAN PENGEMBANGAN HIPOTESIS}

\section{Futures Market}

Pada awalnya futures market digunakan untuk mempertemukan kebutuhan antara petani dengan pedagang. Ketidakpastian harga panen merupakan alasan utama didirikannya pasar futures. Ketika terjadi kelangkaan hasil panen, harga panen akan menjadi sangat 
mahal. Sedangkan ketika hasil panen melimpah, maka harga panen akan cenderung turun. Dari kondisi ini, baik petani maupun pedagang pembeli hasil panen akan mengalami risiko terhadap ketidakpastian harga hasil panen.

Untuk mengatasi risiko terhadap ketidakpastian harga, petani dan pedagang bertemu untuk menegosiasikan harga sebelum datangnya hari panen. Petani dan pedagang membuat suatu kontrak berjangka yang akan disepakati bersama. Kontrak yang dibuat pada hari itu akan dilaksanakan pada beberapa waktu kemudian dan juga pembayarannya untuk waktu kemudian sesuai dengan isi dari perjanjian kontrak futures tersebut.

Pada perkembangannya yang sangat pesat, pasar futures tidak hanya dilakukan secara fisik, namun juga melalui mekanisme elektronik. Perdagangan secara elektronik ini memungkinkan seorang traders untuk memasuki arena perdagangan melalui perangkat komputer sehingga mempermudah mereka bertemu dengan banyak penjual maupun pembeli (Hull, 2008:3).

\section{Futures Contract}

Kontrak futures merupakan sebuah perjanjian untuk membeli atau menjual aset pada suatu periode waktu tertentu dimasa yang akan datang dengan kepastian harga yang telah disepakati sebelumnya Hull (2008:1). Harga sebuah kontrak futures akan berlawanan dengan harga pada pasar spot, harga bisa lebih tinggi bisa juga lebih rendah. Pada kontrak futures diperlukan sejumlah initial margin, yang merupakan jumlah nominal uang yang perlu disetor oleh investor kepada broker.

Mekanisme futures kontrak adalah pertama kali investor menyetor sejumlah deposit sebagai initial margin dalam melakukan perdagangan futures selanjutnya. Kemudian investor akan melakukan kontrak futures dengan memperhatikan aset yang akan diperdagangkan, ukuran kontrak, price limit dan position limits. Nilai dari kontrak futures dimasa mendatang dipengaruhi oleh instrumen induknya yang ada di pasar spot.

Berbeda dengan kontrak forward, kontrak futures dapat dieksekusi sebelum tanggal jatuh tempo dengan cara mengambil posisi yang berlawanan sehingga tidak perlu terjadi adanya delivery. Pada bulan penyelesaian yang tertera di kontrak tidak lagi dilakukan perdagangan dan harga ditentukan oleh bursa atas penyelesaian kontrak. Selain itu, kontrak dapat diselesaikan dengan tanggal penyelesaian terdekat atau yang biasa disebut dengan kontrak futures dekat waktu. Namun pada kontrak futures diperlukan daily settlement dimana apabila nilai aset investor dibawah initial margin maka broker akan memberikan margin call pada investor tersebut (Madura, 1997:125). Kontrak futures dapat digunakan baik pada keuangan maupun komoditi.

\section{Futures Contract Commodities}

Komoditi merupakan aset yang pertama kali diperdagangkan pada pasar futures. Bursa berjangka komoditi banyak digunakan oleh kalangan bisnis sebagai sarana lindung nilai (hedging). Dalam prakteknya bursa berjangka komoditi tidak hanya digunakan untuk hedging. Para spekulan memanfaatkan bursa berjangka komoditi untuk memperoleh laba, sehingga spekulan juga menyediakan likuiditas terhadap bursa berjangka komoditi (http://id.wikipedia.org)

Bursa futures tertua adalah Chicago Board of Trade yang didirikan pada tahun 1848 dengan tujuan utama untuk memperdagangkan kontrak futures komoditi pertanian. CBOT (Chicago Board of Trade) dibentuk oleh para pengusaha pertanian di Amerika sebagai solusi atas fluktuasi harga komoditas biji-bijian (grains). Saat itu diperkenalkan transaksi forward contract yang kemudian berkembang menjadi futures contract (kontrak berjangka) 
(http://www.vibiznews.com). Seorang petani gandum dapat menjual kontrak berjangka gandum yang akan dipanennya beberapa bulan kemudian dan mendapatkan jaminan harga yang akan diterimanya kelak pada saat hasil panen diserahkan. Seoarang pedagang gandum membeli kontrak yang disepakati dengan petani gandum tersebut untuk mendapatkan jaminan bahwa harga tidak akan naik pada waktu hasil panen kelak akan dikirimkan. Dari proses kesepakatan kontrak berjangka ini, petani gandum akan terlindungi dari kejatuhan harga dan pedagang gandum terhindar dari kenaikan harga yang tidak diinginkan.

Secara hukum, penjual kontrak futures berkewajiban untuk menyerahkan obyek kontrak kepada pembeli kontrak futures pada hari penyerahan (delivery date). Namun, pada kenyaataanya banyak kontrak yang ditutup posisinya sebelum delivery date sehingga tidak ada penyerahan obyek kontrak (Sharpe, 1981:457). Investor yang melakukan kontrak futures, baik pada posisi short atau long, dapat menutup kontraknya dengan mengambil posisi yang berlawanan dari awal kontrak sebelum delivery date.

Menurut Madura (2000:126), korporasi yang memiliki posisi terbuka pada perdagangan bisa mempertimbangkan untuk membeli atau menjual kontrak futures untuk menutupi posisi tersebut. Korporasi akan mengunci harga dengan membeli kontrak yang sesuai dengan posisi pada pasar futures. Dengan demikian, risiko perubahan harga bisa dihindarkan dengan menggunakan kontrak futures tersebut. Perusahaan yang akan menjual suatu komoditi, untuk menutupi resiko penurunan harga, maka perusahaan tersebut hendaknya menjual kontrak futures (long position) yang sesuai dengan komoditi di spot atau setidaknya komoditi lain yang memiliki arah pergerakan harga searah dengan komoditi tersebut. Begitu juga sebaliknya, perusahaan yang akan membeli suatu komoditi, untuk menutupi resiko kenaikan harga, maka perusahaan tersebut hendaknya menjual kontrak futures (long position).

\section{Forward Contract}

Hull (2008:5) menyatakan, kontrak forward hampir sama dengan kontrak futures pada perjanjian untuk membeli atau menjual aset pada waktu tertentu di masa yang akan datang dengan harga yang tertentu. Namun, kontrak futures diperdagangkan pada lantai bursa sedangkan kontrak forward diperdagangkan pada pasar over-the-counter. Pasar over-the-counter (OTC) merupakan pasar perdagangan alternatif yang menghubungkan dealers melalui jaringan telepon dan komputer sehingga tidak terjadi pertemuan secara fisik antar dealers.

Tabel 2.1

Perbandingan Kontrak Forward dengan Futures

\begin{tabular}{|c|c|}
\hline Forward & Futures \\
\hline a. Kontrak privat antara dua pihak & a. Diperdagangkan dilantai bursa \\
\hline b. Tidak terstandardisasi & b. Terstandardisasi \\
\hline $\begin{array}{l}\text { c. Biasanya menggunakan satu hari } \\
\text { penyerahan yang spesifik }\end{array}$ & c. Range of delivery dates \\
\hline $\begin{array}{l}\text { d. Penyesuaian (settlement) pada akhir } \\
\text { kontrak }\end{array}$ & $\begin{array}{l}\text { d. Penyesuaian secara harian (daily } \\
\text { settlement) }\end{array}$ \\
\hline e. Delivery atau final cash settlement & $\begin{array}{l}\text { e. Kontrak biasanya ditutup sebelum jatuh } \\
\text { tempo (maturity) }\end{array}$ \\
\hline f. Credit risk & f. Tidak ada credit risk \\
\hline
\end{tabular}

Sumber : Hull (2008:39) 


\section{Long Hedges}

Investor yang berencana untuk membeli saham di masa yang akan datang, namun investor tersebut ingin memastikan harganya, maka investor tersebut harus mengambil posisi kontrak beli di masa yang akan datang, sehingga berapapun harga yang terbentuk pada saat jatuh tempo, investor tetap akan membeli saham tersebut dengan harga yang telah ditetapkan sebelumnya. long hedges merupakan ketepatan perkiraan dari hedger ketika mengetahui waktu yang tepat untuk membeli sejumlah aset dan menginginkan harga yang pasti di masa yang akan datang Hull (2008:47).

Sebagai contoh seoarang importir yang akan mengeluarkan dollar pada empat bulan kedepan. Importir akan merealisasikan keuntungan jika nilai dollar melemah relatif terhadap rupiah. Posisi long futures akan menyebabkan kerugian jika nilai dollar mengalami pelemahan dan memperoleh keuntungan jika nilai dollar mengalami penguatan.

\section{Short Hedges}

Investor yang berencana untuk menjual saham portofolionya di masa yang akan datang, namun investor tersebut ingin memastikan pendapatannya, maka untuk melindungi nilai portofolionya, investor tersebut harus mengambil posisi kontrak jual di masa yang akan datang, sehingga berapapun harga yang terbentuk pada saat jatuh tempo, investor tetap akan menjual saham tersebut dengan harga yang telah ditetapkan sebelumnya. Short hedges merupakan ketepatan perkiraan dari hedger yang telah memiliki sejumlah aset dan mengharapkan menjualnya di masa yang akan datang dengan harga yang telah pasti (Hull, 2008:47).

Short hedges juga dapat digunakan untuk aset yang tidak dimiliki pada saat ini, namun akan dimiliki pada suatu waktu dimasa yang akan datang. Sebagai contoh seoarang eksportir yang akan menerima dollar pada empat bulan kedepan. Eksportir akan merealisasikan keuntungan jika nilai dollar menguat relatif terhadap rupiah. Posisi short futures akan menyebabkan kerugian jika nilai dollar mengalami penguatan dan memperoleh keuntungan jika nilai dollar mengalami penurunan.

\section{Pengembangan Hipotesis}

Bhargava (2007), meneliti perbandingan rasio yang optimal terhadap kontrak futures pasar komoditas kapas dengan kedelai. Penelitian ini menggunakan data dari tahun 1995 hingga 2000, dengan menggunakan 10 model yang digolongkan dalam tiga kategori yakni, metode tradisional regresi, metode regresi yang di modifikasi, dan model error-correction. Hasil dari penelitian ini mengidentifikasikan bahwa metode regresi yang dimodifikasi dan model error-correction mampu menunjukkan efektivitas hedging menggunakan kontrak futures dari komoditas kapas dan kedelai.

Hasil penelitian Ripple dan Moosa (2004), futures hedging lebih efektif ketika menggunakan nilai yang mendekati akhir kontrak. Pada penelitian ini menggunakan data harian dan bulanan dari crude oil futures dengan harga spotnya pada New York Mercantile Exchange (NYMEX) untuk mengukur rasio hedge selama periode pengamatan dari 2 Januari 1998 hingga 29 April 2005. kesimpulan dari penelitian ini menyatakan bahwa rasio hedge akan lebih rendah pada nilai yang mendekati akhir kontrak.

Wisantyo (2006), melakukan penelitian terhadap analisis investasi pada kontrak berjangka komoditi emas dan olein yang ditinjau dari risiko dan tingkat pengembaliannya dengan menggunakan metode Capital Asset Pricing Model (CAPM). Data yang digunakan adalah data sekunder dari data harga komoditi harian emas dan olein pada periode Oktober 2001 hingga Maret 2004. Hasil dari penelitian ini menunjukkan tingkat pengembalian pasar $\left(R_{m}\right)$ lebih besar dibandingkan dengan tingkat pengembalian bebas risiko ( $\left.R_{f}\right)$. Komoditi emas 
lebih sensitif terhadap pasar sehingga investasi di komoditi emas cenderung lebih berisiko jika dibandingkan dengan komoditi olein, namun emas memiliki return yang tinggi dibandingkan dengan komoditi olein. Sehingga keputusan investasi sebaiknya dijatuhkan pada pilihan komoditi emas. Berdasarkan penelitian tersebut diatas, maka hipotesis penelitian ini adalah:

$\mathrm{H}_{1}$ : Terdapat perbedaan varians return bulanan hedged komoditi emas dengan varians return bulanan hedged komoditi olein.

Kerangka Pemikiran

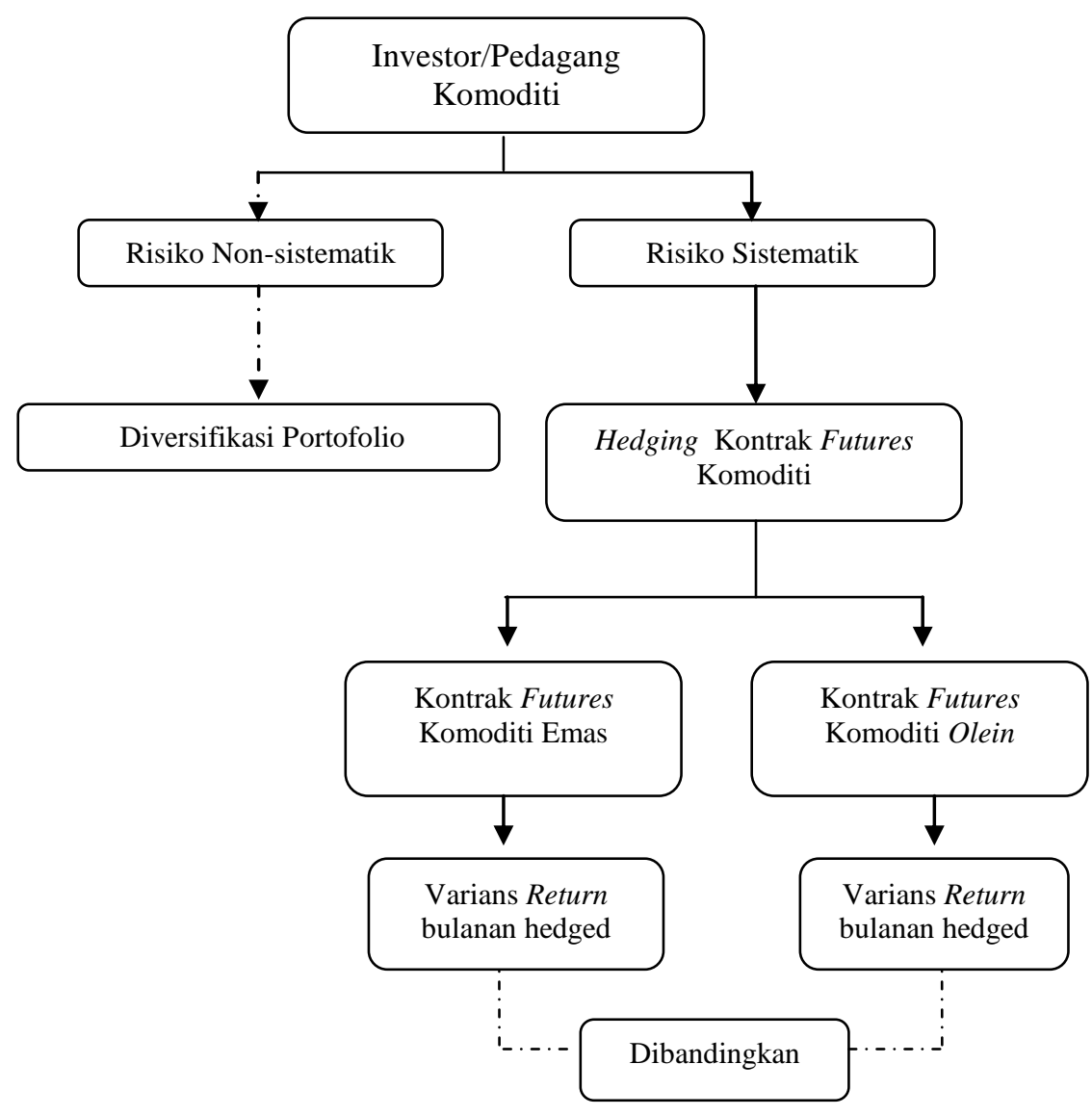

\section{METODA PENELITIAN}

Sampel

Sampel penelitian perbandingan efektivitas hedging dengan kontrak futures komoditi ini menggunakan data sekunder perdagangan harian emas dan olein yang diperdagangkan pada Bursa Berjangka Jakarta selama Januari 2005 sampai Januari 2010, untuk data bulan Mei 2005 tidak dimasukkan dalam variabel penelitian dikarenakan adanya ketidaklengkapan data pada harga futures kedua komoditi. Data spot olein diperoleh dari lembaga Bappebti, sedangkan data spot emas diperoleh dari USA GOLD dimana data harus dikonversikan terlebih dahulu kedalam Rupiah pergram dengan kurs beli (bid price) pada BI. Data penelitian ini berupa data mingguan spot price dan settlement price. Pada penelitian ini menggunakan kontrak yang mendekati jatuh tempo dan di roll-over pada waktu akan berakhir. 


\section{Definisi Operasional}

Agar estimasi model yang dilakukan dapat memberikan hasil yang akurat, maka salah satu syaratnya adalah penggunaan data yang tepat sebagai proxy variabel-variabel yang digunakan dalam model. Berikut ini adalah data-data yang digunakan dalam penelitian untuk mem-proxy atas variabel-variabel dalam model:

Varians return bulanan hedged portofolio.

Varians return bulanan hedged komoditi merupakan ukuran penyebaran atau variabilitas pendapatan bulanan portofolio menggunakan kontrak futures.

1. Kontrak Futures Komoditi Emas

Kontrak futures komoditi emas merupakan kontrak berjangka yang memiliki underlying asset berupa emas. Emas tidak hanya dikenal sebagai suatu komoditi pertambangan tetapi juga sebagai suatu produk, alat moneter dan instrumen investasi. Sebagai alat penyimpan kekayaan, nilai dari emas dapat bertahan tinggi dari fluktuasi nilai tukar mata vang. Sehingga emas merupakan salah satu alat lindung nilai yang baik.

\section{Kontrak Futures Komoditi Olein}

Olein adalah minyak goreng dari hasil olahan minyak sawit mentah atau biasa dikenal dengan crude palm oil (CPO), sedangkan CPO sendiri merupakan hasil dari proses pemerasan buah kelapa sawit. CPO diolah menjadi dua produk utama :
a. Stearin
Merupakan fraksi pada dari minyak kelapa sawit yang biasanya digunakan untuk margarin, shortening, dan bahan baku industri sabun dan deterjen.
b. Olein
Merupakan fraksi cair dari minya kelapa sawit yang digunakan sebagai bahan baku pembuatan minyak goreng.

Dalam melakukan analisi harga berjangka olein, maka tidak lepas dari perkembangan harga crude palm oil, kelapa sawit, komoditi substitusi atau komplementer maupun produk akhir (end product) dengan bahan baku minyak sawit. Harga minyak kelapa sawit bersifat global dikarenakan konsumen dari komoditi ini bersifat internasional.

Varians return (Jones, 2002:145) dihitung dengan rumus sebagai berikut :

$$
\sigma^{2}=\sum_{\mathrm{t}=1}^{\mathrm{n}} \frac{\left(\mathrm{R}_{\mathrm{b}}-\overline{\mathrm{R}}\right)}{\mathrm{n}-1}
$$
Keterangan:
$\sigma^{2}$ : varians perubahan harga
$\mathrm{R}_{\mathrm{b}}$ : rata-rata return bulanan portofolio
$\bar{R}$ : rata-rata return portofolio selama periode observasi
$n$ : jumlah observasi

\subsubsection{Hedge Effectiveness}

Pengukuran efektivitas ini menentukan varians dari portofolio yang dihedged Ripple dan Moosa (2007).

$$
\operatorname{Var}_{(\text {hedged })}=\sigma_{s}^{2}+h^{* 2} \sigma_{f}^{2}-2 h^{*} \sigma_{s f}
$$

Keterangan:

$$
\begin{array}{ll}
\operatorname{Var}_{\text {(hedged) }} & =\text { varians hedged portofolio } \\
\sigma_{s} & =\text { standar deviasi dari nilai spot }
\end{array}
$$




$$
\begin{array}{ll}
\sigma_{f} & =\text { standar deviasi dari nilai futures } \\
h^{*} & =\text { rasio hedge } \\
\sigma_{s h} & =\text { kovarians dari posisi spot dan futures }
\end{array}
$$

Sedangkan return dari hedged portofolio (Switzer and Mario, 2006) dirumuskan sebagai berikut :

$$
R h=\left(S_{\dagger}-S_{t-1}\right)-h^{*}\left(F_{\dagger}-F_{t-1}\right)
$$

Keterangan:

$$
\begin{array}{ll}
\mathrm{Rh} & =\text { return hedged portofolio } \\
h^{*} & =\text { rasio hedge } \\
\mathrm{S}_{t}, \mathrm{~F}_{t} & =\text { harga spot dan futures periode } \dagger \\
\mathrm{S}_{t-1}, \mathrm{~F}_{t-1} & =\text { harga spot dan futures periode } \dagger
\end{array}
$$

Dan untuk menghitung return bulanan (Jones, 2002:140) digunakan rumus :

$$
\mathrm{Rb}=\sum \mathrm{Rn} / \mathrm{n}
$$

\subsection{Model Analisis}

Model analisis yang akan digunakan dalam penelitian ini adalah sebagai berikut (Ripple dan Moosa (2007):

$$
\frac{\sigma^{2} R_{h o}}{\sigma^{2} R_{h e}}=F\left(n_{h e-1}, n_{h o-1}\right)
$$

$$
\begin{aligned}
& \text { Keterangan: } \\
& \begin{aligned}
\sigma^{2} R_{h o} & =\text { Varians Return Hedged Olein } \\
\sigma^{2} R_{h e} & =\text { Varians Return Hedged Emas } \\
n-1 & =\text { derajat kebebasan }
\end{aligned}
\end{aligned}
$$

\subsection{Teknik Analisis}

Teknik analisis dilakukan dengan menggunakan bantuan program Microsoft Excel, EVIEWS, dan SPSS 11.5 for windows melalui tahap-tahap sebagai berikut :

1. Mentabulasikan data harian harga futures dan spot komoditi emas dan olein periode Januari 2005 sampai Januari 2010.

2. Mentabulasikan nilai tukar Rupiah terhadap US Dollar untuk mengkonversikan harga emas spot per-ounce dalam USD kedalam gram Rupiah. Konversi emas menggunakan rumus:

$$
\text { Emas }(\text { Rp / gram })=\frac{H \arg \text { a emas }(\text { USD/ounce })}{31,1035} \times \operatorname{kurs}(\text { USD / Rp })
$$

$$
1 \text { ounce }=31,1035 \text { gram }
$$

3. Mentabulasikan data mingguan harga futures dan spot komoditi emas dan olein periode Januari 2005 sampai Januari 2010, tanpa data bulan Mei tahun 2005.

4. Melakukan uji korelasi harga spot dan futures kedua komoditi untuk menentukan apakah kedua komoditi tersebut memiliki hubungan sehingga dapat dilakukakan tracking agar bisa digunakan sebagai sarana hedging yang baik.

5. Menghitung return data mingguan spot komoditi.

Return dihitung menggunakan rumus :

$$
R s=\left(S_{t}-S_{t-1}\right)
$$

6. Menghitung return data mingguan futures komoditi.

Return dihitung menggunakan rumus : 


$$
R s=\left(F_{\dagger}-F_{t-1}\right)
$$

7. Melakukan uji akar unit (test of unit roots) dengan metode ADF (Augmented DickeyFuller) test untuk menentukan apakah data yang digunakan stasioner atau tidak. Data yang stasioner memiliki kriteria yaitu jika rata-rata dan variansnya konstan sepanjang waktu, kovarian antara dua data runtut waktu hanya tergantung dari kelambanan antara dua periode waktu tersebut.

8. Menghitung masing-masing rasio hedge tiap komoditi dengan menggunakan dengan bantuan program eviews menggunakan OLS, model yang digunakan adalah sebagai berikut:

$$
\Delta S=a+h^{*} \Delta F+\varepsilon
$$

dimana $h$ ' adalah rasio hedge

9. Menghitung return hedged mingguan masing-masing komoditi dengan rumus:

$$
R h=\left(S_{t}-S_{t-1}\right)-h^{*}\left(F_{t}-F_{t-1}\right)
$$

10. Menghitung rata-rata return hedged bulanan masing-masing komoditi dengan menggunakan rumus:

$$
\mathrm{Rb}=\sum \mathrm{Rn} / \mathrm{n}
$$

11. Melakukan uji perbedaan dengan cara menguji dua data independen menggunakan independent $t$ test.

\section{HASIL DAN PEMBAHASAN}

Deskripsi Hasil Penelitian

Setelah mentabulasikan harga penutupan spot dan futures komoditi emas dan olein, dilakukan penghitungan korelasi untuk mengetahui market track aset dan instrumen hedge sehingga bisa digunakan sebagai sarana hedging. Berikutnya dilakukan penghitungan return mingguan dari harga spot dan futures komoditi emas dan olein. Deskripsi variabel penelitian untuk masing-masing variabel yang digunakan dalam model dijelaskan sebagai berikut :

\section{Rasio Hedge}

Nilai dari rasio hedge sangatlah bervariasi. Nilai rasio hedge digunakan untuk menentukan jumlah kontrak dalam mengeliminasi kerugian di pasar fisik. Nilai rasio hedge satu menunjukkan bahwa untuk mengeleminasi kerugian dari harga fisik diperlukan sejumlah kontrak futures yang senilai dengan jumlah kontrak di pasar fisik. Jika nilai rasio hedge $<1$, maka nilai kontrak futures yang diperlukan lebih kecil dari nilai kontrak di pasar fisik. Sedangkan nilai rasio hegde>1, maka untuk mengeliminasi kerugian di pasar fisik diperlukan kontrak yang lebih besar di pasar futures. Berikut ini adalah tabel hasil perhitungan hedge ratio dengan menggunakan model Ordinary Least Square.

Tabel 4.1

Hedge Ratio Emas dan Olein

\begin{tabular}{|l|c|c|}
\hline \multicolumn{2}{|c|}{ Emas } & Olein \\
\hline Hedge Ratio & 0.558366 & 0.963665 \\
R-squared & 0.225932 & 0.646700 \\
Adjusted R-squared & 0.222666 & 0.645209 \\
\hline
\end{tabular}

Tabel 4.1 menunjukkan rasio hedge dari emas lebih kecil dari rasio hedge emas, hal ini mengindikasikan bahwa untuk mengeleminasi kerugian di pasar fisik, diperlukan kontrak yang lebih besar untuk komoditi olein dibandingkan bila mengeleminasi kerugian di pasar fisik bagi komoditi emas. Hal ini disebabkan karena fluktuasi di pasar spot olein terhadap 
fluktuasi pasar futures olein lebih besar dibandingkan dengan fluktuasi pasar fisik emas terhadap pasar futuresnya. Sehingga untuk mengeleminasi kerugian dipasar fisik olein diperlukan kontrak futures yang lebih besar dari pada mengeleminasi kerugian di pasar fisik emas.

\section{Efektivitas Hedging}

Efektivitas hedging merupakan ukuran kemampuan dari aktivitas hedging untuk mengeleminasi risiko dari fluktuasi harga di pasar fisik. Hedging dikatakan efektif bila perubahan harga futures dapat mengimbangi perubahan harga spot. Setelah menentukan rasio hedge dari tiap-tiap komoditi kemudian dilakukan penghitungan return hedged dari masing-masing komoditi. Berikut adalah hasil perhitungan return hedged dari masing-masing komoditi.

Tabel 4.2

Return dan Varians Return Hedged Emas dan Olein

\begin{tabular}{|l|c|c|c|c|}
\hline \multirow{2}{*}{} & \multicolumn{2}{|c|}{ Return Hedged } & \multicolumn{2}{c|}{ Varians Return Hedged } \\
\cline { 2 - 5 } & Emas & Olein & Emas & Olein \\
\hline Mean & 0.0020875 & 0.0005131 & 0.0010047 & 0.0014333 \\
\hline Max & 0.0652618 & 0.0211952 & 0.0062939 & 0.0546901 \\
\hline Min & -0.0232461 & -0.0194316 & 0.0000330 & 0.0000005 \\
\hline Obs & 60 & 60 & 60 & 60 \\
\hline
\end{tabular}

Rata-rata return hedged terbesar dihasilkan oleh komoditi emas dengan nilai $0.00209 \%$ lebih besar $0.00157 \%$ dibanding dengan return hedged komoditi olein. Dilihat dari angka varians returnnya, komoditi olein memiliki rentang varians return yang cukup lebar dari $0.0000005 \%$ hingga $0.0546901 \%$. Hal ini menunjukkan risiko komoditi olein lebih besar dibandingkan dengan risiko dari komoditi emas, dimana rentang varians return emas mulai dari 0.0000330 $\%$ hingga $0.0062939 \%$.

\section{Analisis Model dan Pembuktian Hipotesis}

Sebelum melakukan penghitungan hedge ratio dengan menggunakan model OLS, terlebih dahulu dilakukan uji akar unit (unit root test) untuk mengetahui apakah data yang digunakan bersifat stasioner atau non-stasioner. Jika data masih bersifat non-stasioner, maka data harus ditransformasi terlebih dahulu agar menjadi satasioner. Data yang akan di uji kestasionerannya adalah return mingguan dari masing-masing komoditi baik return dari spot maupun return dari futures.

\section{Uji Akar Unit}

Uji akar unit dalam penelitian ini menggunakan metode ADF (Augmented Dicky-Fuller). Uji akar unit ini untuk mengetahui apakah data return spot dan futures dari tiap-tiap komoditi sebelum dilakukan regresi dengan OLS bersifat stasioner atau non-stasioner. Berikut hasil uji akar unit data return spot dan futures komoditi emas dan olein.

Tabel 4.3

Hasil Uji Akar UnitReturn Spot dan Futures Komoditi Emas dan Olein

\begin{tabular}{|c|l|c|c|c|c|c|}
\hline \multirow{2}{*}{ Variabel } & ADF & \multirow{2}{*}{\begin{tabular}{c} 
ADob \\
\cline { 5 - 7 }
\end{tabular}} & Statistic & & \multicolumn{3}{c|}{ Critical Value at } \\
\hline Emas & Spot & -17.39239 & 0.0000 & -3.457747 & -2.873492 & -2.573215 \\
\hline & Futures & -14.71659 & 0.0000 & -3.457747 & -2.873492 & -2.573215 \\
\hline Olein & Spot & -16.99403 & 0.0000 & -3.457747 & -2.873492 & -2.573215 \\
\hline & Futures & -15.04277 & 0.0000 & -3.457747 & -2.873492 & -2.573215 \\
\hline
\end{tabular}


Tabel hasil uji akar unit dengan metode ADF (Augmented Dicky-Fuller) menunjukkan bahwa nilai ADF statistic untuk keseluruhan variabel baik komoditi emas dan olein meninjukkan nilai yang lebih kecil dibandingkan dengan nilai kritis pada semua level. Hal ini menunjukkan variabel yang digunakan bersifat stasioner. Hasil ini juga bisa dilihat dari nilai probabilitas yang menunjukkan angka praktis 0 , sehingga data yang digunakan dalam penelitian bersifat stasioner.

Dari hasil uji akar yang mengindikasikan data yang digunakan adalah stasioner dapat diketahui bahwa rata-rata dan varians kedua data yang diteliti bersifat konstan. Disamping itu kovarian antara dua data runtut waktunya tergantung pada kelambanan antara dua periode tersebut. Jika data yang digunakan bersifat non-stasioner, maka data harus distasionerkan terlebih dahulu dengan cara di deferensiasi (Winarno, 2007).

Setelah diketahui bahwa return kedua data bersifat stasioner, maka dilanjutkan dengan meregresi return spot sebagai variabel dependen dengan variabel return futures sebagai variabel independen. Hasil koefisien regresi variabel independen merupakan rasio hedge optimum sebagai parameter untuk menentukan return hedged dan varians return hedged.

\section{Uji Statistik Independent t-test}

Setelah melakukan penghitungan hedge ratio untuk menentukan nilai return hedged dari tiap-tiap komoditi kemudian dilanjutkan dengan menghitung rata-rata return hedged dan varians return hedged bulanan, maka diperlukan uji $F$ untuk mengetahui perbedaan nyata antara varians return bulanan hedged komoditi emas dengan varians return hedged komoditi olein. Dalam uji ini, rumusan hipotesa yang digunakan adalah:

Ho: $\sigma_{h e^{2}}=\sigma_{h o}{ }^{2}$ berarti tidak terdapat perbedaan yang signifikan antara varians return hedged bulanan komoditi emas dengan varians return hedged bulanan komoditi olein.

$H_{1}: \sigma_{h e^{2}} \neq \sigma_{h h^{2}}$ berarti terdapat perbedaan yang signifikan antara varians return hedged bulanan komoditi emas dengan varians return hedged bulanan komoditi olein.

Tabel 4.4

Hasil Independent t-test Varians Return Hedged Komoditi Emas dan Olein

\begin{tabular}{|c|c|c|c|c|c|c|c|c|c|c|}
\hline & \multicolumn{2}{|c|}{$\begin{array}{l}\text { Levene's Test for } \\
\text { Equality of Variances }\end{array}$} & \multicolumn{7}{|c|}{ t-test for Equality of Means } \\
\hline & & \multirow[b]{2}{*}{$\mathrm{F}$} & \multirow[b]{2}{*}{ Sig. } & \multirow[b]{2}{*}{$t$} & \multirow[b]{2}{*}{$d f$} & \multirow[b]{2}{*}{ Sig. (2-tailed) } & \multirow{2}{*}{$\begin{array}{c}\text { Mean } \\
\text { Diff erence }\end{array}$} & \multirow{2}{*}{$\begin{array}{l}\text { Std. Error } \\
\text { Difference }\end{array}$} & \multicolumn{2}{|c|}{$\begin{array}{l}95 \% \text { Confidence } \\
\text { Interval of the } \\
\text { Difference }\end{array}$} \\
\hline & & & & & & & & & Lower & Upper \\
\hline VARIANS & $\begin{array}{l}\text { Equal variances } \\
\text { assumed }\end{array}$ & 1.733 & .191 & -.463 & 118 & .644 & -.0004286 & .00092573 & -.002262 & .00140462 \\
\hline & $\begin{array}{l}\text { Equal variances } \\
\text { not assumed }\end{array}$ & & & -.463 & 63.206 & .645 & -.0004286 & .00092573 & -.002278 & .00142123 \\
\hline
\end{tabular}

Berdasarkan hasil levene's test untuk menguji kesamaan varians (equality of variances) antara varians return hedged komoditi emas dengan varians return hedged komoditi olein menunjukkan tingkat signifikansi 0,191 dan nilai $F$ sebesar 1,733. Tingkat signifikansi sebesar 0,191 menunjukkan bahwa hipotesa kesamaan varians antara varians return hedged komoditi emas dengan varians return hedged komoditi olein tidak ditolak. Hal ini berarti bahwa varians return hedged komoditi emas sama dengan varians return hedged komoditi olein. 


\section{Pembahasan}

Kontrak futures komoditi merupakan salah satu instrumen lindung nilai sebuah aset komoditi dari risiko sistimatis. Risiko dapat dialihkan kepada para spekulan yang mengharapkan keuntungan dari bursa berjangka. Dengan melakukan hedging, diharapkan keuntungan atau kerugian yang ada di pasar spot dapat tertutupi dengan kerugian atau keuntungan yang diperoleh di pasar futures.

Hasil uji korelasi menunjukkan tingkat korelasi harga spot emas terhadap futures emas sebesar 0.996. Kontrak futures emas memiliki track yang baik terhadap harga spot emas. Sama halnya dengan kontrak futures komoditi olein yang memiliki korelasi yang kuat terhadap pergerakan harga spotnya. Korelasi yang kuat ini dikarenakan kedua kontrak futures menggunakan underlying yang sama pada masing-masing komoditi. Nilai korelasi bisa bertambah kuat atau melemah tergantung kondisi pasar pada tiap-tiap komoditi. Dengan menggunakan model ordinary least square (OLS) untuk menentukan nilai hedge ratio, ditemukan nilai hedge ratio kontrak futures emas lebih kecil dibandingkan dengan hedge ratio kontrak futures olein. Namun, saat uji beda terhadap varians return hedged komoditi emas dengan varians return hedged komoditi olein, hasil analisis menunjukkan bahwa $\mathrm{H}_{0}$ tidak ditolak. Hal ini mengindikasikan bahwa varians return dari hedged komoditi emas memiliki nilai yang sama dengan varians return hedged komoditi olein.

Efektivitas strategi hedging tergantung pada ketersedian instrumen hedging yang cocok. Semakin tinggi korelasi pergerakan harga komoditi dengan pergerakan harga futures, maka akan semakin efektif strategi hedging tersebut. Selain itu estimasi rasio hedge dan basis risk juga harus diperhitungkan dalam melakukan strategi hedging. Hedge ratio digunakan sebagai ukuran untuk menentukan kontrak futures yang akan diambil. Estimasi rasio hedge yang optimal akan menentukan tingkat penyetaraan keuntungan maupun kerugian yang akan terjadi di pasar spot dan futures. Cross hedging dapat dilakukan jika komoditi yang akan dihedged tidak terdapat kontrak futuresnya, maka sebagai alternatifnya dapat digunakan kontrak futures komoditi lain yang memiliki pergerakan harga yang sama. Dari uji statistik pearson correlation, korelasi spot emas dengan futures olein sebesar 0,694 sedangkan korelasi spot olein dengan futures emas sebesar 0,691. Hal ini merupakan indikator bahwa futures emas dapat digunakan untuk menghedge komoditi olein, dan futures olein dapat digunakan untuk menghedge komoditi emas sehingga antar keduanya dapat dilakatakan sebagai cross hedging.

Pada penelitian Wisantyo (2006) mengenai analisis perbandingan investasi pada kontrak futures emas dan olein menemukan bahwa berinvestasi pada kontrak futures emas memiliki risiko dan return yang tinggi bila dibandingkan dengan kontrak futures olein yang meskipun risikonya rendah, tingkat return yang dihasilkan relatif lebih rendah dibandingkan return kontrak futures emas. Namun berdasarkan hasil penelitian ini, bila kontrak futures kedua komoditi digunakan sebagai sarana hedging akan menghasilkan varians return yang sama, sehingga sama-sama efektif untuk mengurangi dampak dari risiko sistimatis.

\section{KESIMPULAN DAN SARAN}

\section{Kesimpulan}

Berdasarkan hasil analisis dan pembahasan yang telah diuraikan pada bab sebelumnya, maka hasil penelitian ini dapat disimpulkan sebagai berikut :

1. Model Ordinary Least Square yang digunakan pada penelitian ini menunjukkan hasil rasio hedge komoditi olein lebih besar dibandingkan dengan rasio hedge komoditi emas. Model penentuan rasio hedge tidaklah mempengaruhi efektivitas hedging seperti pada penelitian yang dilakukan oleh Ester Agustina (2006), penelitian tersebut menemukan tidak adanya perbedaan hedging effectiveness (return dan varians return) yang signifikan dengan menggunakan ketiga model : OLS, VAR, dan VECM. 
2. Varians return hedged komoditi emas memiliki nilai yang sama dengan varians return hedged komoditi olein. Meskipun volalitas komoditi olein lebih tajam dibandingkan dengan emas, namun ketika di hedge dengan rasio yang lebih besar dari rasio hedge emas, akan menghasilkan nilai varians return yang sama. Sehingga penanganan risiko sistimatis oleh hedger emas dan hedger olein sama-sama efektif.

Saran

Saran yang dapat diberikan dari penelitian ini adalah:

1. Investor atau pedagang komoditi dapat mempertimbangkan ketersediaan sarana hedging untuk melindungi posisi pada pasar fisik. Jika komoditi yang akan di hedge tidak tersedia kontrak futuresnya, maka bisa menggunakan alternatif kontrak futures komoditi lain yang memiliki korelasi kuat dengan komoditi yang akan di hedge dengan menentukan terlebih dahulu rasio hedge yang optimal untuk menyesuaian nilai kontrak antara aset yang di hedge dengan instrumen hedge.

2. Sebaiknya dilakukan penelitian yang lebih mendalam mengenai cross hedging antar komoditi emas dengan olein.

3. Dilakukan penelitian lebih lanjut mengenai efektivitas hedging pada komoditi-komoditi lain sebagai bahan pertimbangan multiple cross hedging.

\section{DAFTAR PUSTAKA}

Agustina, Ester. 2006. Perbandingan Model Ordinary Least Square, Vector Autoregression, dan Vector Error Correction Model Untuk Menghitung Hedge Ratio dan Hedging Effectiveness Indeks Lq45 Futures Di Pasar Derivatif Bursa Efek Surabaya. Universitas Airlangga. Surabaya.

Ardhlanto, Sulaiman. 2006. Efektivitas Strategi Hedging Kontrak Futures LQ45 Dalam Mengurangi Risiko Sistimatis Portofolio. Universitas Airlangga. Surabaya.

Bhargava, Vivek. 2007. Determining the Optimal Hedge Ratio: Evidence from cotton and Soybean Markets. Philadelpia.

Bodie, Zvi, et al. 2006. Investment. Edisi keenam, jilid 1. Terjemahan. Penerbit Salemba Empat, Jakarta.

Brigham, Eugene F, dan Joel F. Houston. Manajemen Keuangan. Edisi kedelapan, jilid 1. Terjemahan. Penerbit Erlangga, Jakarta.

Fabozzi, Frank J. 2000. Manajemen Investasi. Jilid 2. Terjemahan. Penerbit Salemba Empat, Jakarta.

Hull, Jhon C. 2008. Fundamentals Of Future And Options Markets. Sixth Edition. Penerbit Pearson Prentice Hall, New Jersey.

Jones, C P. 2002. Investment: Analysis and Management. Eight Edition. New York: John Willey \& Son, Inc.

Madura, Jeff. 1997. Manajemen Keuangan Internasional. Edisi keempat, jilid 1, Terjemahan. Penerbit Erlangga, Jakarta.

Ripple, Ronald D, dan Imad A Moosa. 2007. Futures Maturity and Hedging Effectiveness:The Case Of Oil Futures. La Trobe University.

Santoso, Singgih. 2005. Mengatasi Berbagai Masalah Statistik Dengan SPSS Versi 11.5. PT. Elex Media Komputindo. Jakarta

Sharpe, William F. 1981. Investments. Second Edition. Prentice Hall, New Jersey.

Switzer, Lorne N, and Mario El-Khoury. 2006. Extreme Volatility, Speculative Efficiency, and the Hedging Effectiveness of the Oil Futures Markets. Concordia University. Canada.

Winarno, W. Wahyu. 2007. Analisis Ekonometrika Dan Statistika Dengan Eviews. UPPT STIM YKPN. Yogyakarta.

Wisantyo, Edwin. 2006. Analisis Perbandingan Investasi Kontrak Berjangka Komoditi Ditinjau Dari Risiko Dan Tingkat Pengembaliannya Dengan Menggunakan Metode CAPM (Studi Kasus: Komoditi Olein Dan Emas). Universitas Indonesia, Jakarta. 